\title{
Moderation Effect of Perceived Benefits of Loyalty Programs on the Link between Store Attributes and Customer Loyalty
}

\author{
Santosh Kumar Alreddy, Dwarakanath Siriguppi, Mohandas J. Menon \\ Department of Marketing \& Strategy, IBS Hyderabad (A Constituent of the ICFAI Foundation of Higher Education), Hyderabad, India \\ Email: santosh_ab@ibsindia.org
}

How to cite this paper: Alreddy, S.K., Siriguppi, D. and Menon, M.J. (2019) Moderation Effect of Perceived Benefits of Loyalty Programs on the Link between Store Attributes and Customer Loyalty. Theoretical Economics Letters, 9, 2110-2125. https://doi.org/10.4236/tel.2019.96133

Received: July 13, 2019

Accepted: August 26, 2019

Published: August 29, 2019

Copyright ( 2019 by author(s) and Scientific Research Publishing Inc. This work is licensed under the Creative Commons Attribution International License (CC BY 4.0).

http://creativecommons.org/licenses/by/4.0/

\begin{abstract}
The objective of this paper is to examine the moderation effect of perceived benefits of loyalty programs on the link between store attributes and customer loyalty. This study uses data from loyalty program members covering different apparel retailers of Northern districts of Karnataka. In the first step variables were identified through literature review and interview method. In the next step, exploratory factor analysis was performed to identify the critical factors which measure customer loyalty in the apparel retailer's context. Finally, moderation analysis was employed using SPSS and results indicate that perceived benefits of loyalty programs significantly moderate the relationship between stores attributes and customer loyalty.
\end{abstract}

\section{Keywords}

Customer Loyalty, Store Attributes, Loyalty Program, Moderation Analysis

\section{Introduction}

In retailing, relationship marketing has gained importance in both academics and industrial fields as a strategy to manage, develop, and evaluate the relationship between retailers and customers [1] [2] [3] [4] [5]. Studies have shown that relationship-marketing outcomes are influenced by the relational constructs of trust, commitment, relationship satisfaction, and relationship quality influences buying behaviour [6], increases loyalty [7] [8] [9], and the expectation of continuing interaction and willingness to advice [10]. However, often retail business executives are disappointed with the performance of relationship marketing efforts [11] and customers may not want a relationship with a retailer because they consider it to be a burden [12]. 


\subsection{Store Attributes}

Store attributes can be defined as retail environments which arouse consumer's desire to purchase, and these include product, service, and store qualities [13]. The retail store attributes have been found to be one of the significant inputs into the consumer's perceptions of global store image and overall attitudes toward a store [14]. Different stores differ in the combinations of store attributes, but previous studies have identified nine store attribute factors, i.e., store atmosphere (an in-store environment consisting of layout, visual display, colours, lightings, and sounds which create an image of the store in consumer's mind), convenience (accessibility to a shopping mall or a store), merchandise (characteristics of products carried by a store or shopping mall such as quality, selection or assortment, and styles of products), promotions (activities a store undertakes to inform customers of its offerings and images), post-transaction service (physical services relating to products after transactions such as merchandise delivery and installation, product warranties, and exchanges or refunds), direct mail (activities performed by a store or a shopping mall to communicate directly with customers through mail brochures and pamphlets), interpersonal communication (employees interactions with customers in a friendly manner), preferential treatment (a customer's perception that he/she receives special recognition from a store or a mall by means of better service which is unavailable to non-regular customers), and tangible rewards (such as discounts and rewards offered to customers in return for their business with a store or a shopping mall). But, previous studies have shown that a quantitative study is needed to identify the suitable variables in the chosen retailing context.

\subsection{Customer Loyalty and Perceived Benefits of Loyalty Program}

The marketing literature present a broad array of loyalty measures [15], and their effectiveness depends on the particular market and study objective. Conventionally, customer loyalty has been defined as a behavioural measure such as amount of purchase [16], possibility of purchase [17], and purchase behaviour [18]. Shoemaker and Lewis 1999 [19] asserted that customers become loyal toward a retailer when their important needs are taken care by its products and services. "True" customer loyalty is difficult to build and sustain without considering basic attitudinal aspects of customer behaviour into account [20]. In other words, both behavioural and attitudinal aspects of loyalty should be considered simultaneously [21].

The apparent benefits of loyalty program refer to the values that the program provides for members [22]. Therefore, the success of a loyalty program depends on how member observe the program benefits [23]. The perceived benefit produced by loyalty program rewards is the association between the consumer's perceived benefits in relation to the perceived costs of receiving these benefits, and represents a affirmative touching reaction such as prejudiced belief of satisfaction or pleasure, a source of satisfaction and motivation, because the rewards 
fulfil a desire or a goal [24] [25] [26]. By classifying the diverse types of rewards that encourage customer perceived benefit, we can obtain precise motivations that provoke use of these programs. For example, functional rewards are accountable to comprise three fields Frisou and Yildiz, 2011 [27]. Firstly, economical rewards and financial savings which match to an economic purchase motivation-e.g. price reductions, purchase vouchers [28]; secondly, convenience in which they assure commodity motivations e.g. ease of purchase, decrease in shopping time [29]; and lastly informational rewards, which are related to examination [30] [31] [32].

\subsection{Research Gap}

Many retailers fail to identify the appropriate variables and factors leading to customer loyalty intentions in the context of retailers. And off late companies have realised the importance of store attributes in the context of retail, but fail to emphasize the important aspects to get the desired results in the long run. Also from the review of literature it was found that, loyalty programs are the most frequently used marketing activity to induce loyalty among customers in the context of organized apparel retailers. It was intended that, knowing the moderating role of perceived benefits of loyalty programs on the link between store attributes-customer loyalty enables the retailers to formulate strategies to achieve desired results in the long run.

\subsection{Objective of the Study}

To test whether perceived benefits of loyalty programs are moderating the relationship between store attributes and customer loyalty.

\section{Research Methodology}

In this study, firstly a review of literature was carried out by focussing on store attributes, loyalty program and satisfaction by emphasising on customer loyalty in the context of retailers. This literature review has helped in identifying variables and also in knowing the research gap. Considering the variables identified in this study a structured questionnaire was developed. The questionnaire was administered in collecting data from members of loyalty programs in select apparel retail stores of Northern districts of Karnataka. Factor analysis and Moderation analysis was used for analysing the data.

Unstructured interview with members of loyalty program and store managers helped to explore their perception about store attributes, loyalty program benefits and loyalty. Unstructured interview was conducted with 20 loyalty program members and two store managers, which helped in gathering diverse viewpoints on the concepts i.e., store attributes, loyalty program and customer loyalty intentions. This was conducted in Gulbarga which includes Peter England and Levi's store. The structured questionnaire was developed after identifying variables through literature review and interview method. And the pilot study was carried 
out among 30 members of loyalty program at Peter England and Levi's store to finalize the questionnaire. Only those members who are associated with the store at least for a year were selected, since this is considered to be a satisfactorily long period whereby withdrawing from the program is due to frustration or disappointed. Besides, a year time was considered to be a satisfactory to view members as qualified loyalty program members, a feature that signifies the validation of data [33]. As a result of the literature review and the exploratory study of this research work 62 variables were identified to measure the constructs of store environment, merchandise, interpersonal communication, preferential treatment, post transaction service, perceived relationship investment, perceived relationship quality, behavioural and attitudinal loyalty. An unstructured interview with 20 members of loyalty program was carried out at two different retailers i.e., Peter England \& Levi's at Gulbarga city. The participants shared their experiences with retailers regarding loyalty program benefits, store related aspects like ambience, display, availability of variety and quality of apparel, other services rendered in detail.

The store managers were asked to rate each variable as "clearly representative", "somewhat representative", and "not representative". Only items rated as clearly representative and somewhat representative were retained. After elimination the draft questionnaire is divided in to two parts: A and B. The part A contains 55 questions related to loyalty, loyalty program and store attributes. All the items are measured on a five point Likert scale. Section B contains seven questions related to demographic details about the respondents such as Name, Age, Education, Gender, Occupation, Income and Period of membership.

The questionnaire consists of two sections. Section A contains 48 variables (questions) covering both store attribute and loyalty program concepts. A total of seventeen items measures store attributes which consists of store environment, merchandise, interpersonal communication, preferential treatment and post transaction service. Fifteen items are measuring perceived benefits of loyalty program which includes economy, convenience, recognition-social relationship and information. The concept of perceived relationship investment, perceived relationship quality was measured using three items each. Five items measuring attitudinal and behavioural loyalty covering the concept of store attributes, the remaining five items are measuring loyalty (purchase intensity \& resistance to counter persuasion) covering loyalty program concept. All the items are measured on five point Likert scale ranges from $1=$ strongly disagree to $5=$ strongly agree except two questions, measuring behavioural loyalty. The questions are: Of the ten times you select a store at which to buy products, how many times do you select this store? a) 1 - 2, b) 3 - 4, c) 5 - 6, d) 7 - 8, e) 9 - 10; How often would you buy products in this store compared with other stores where you buy products?

a) Very less often, b) Less often, c) Neutral, d) Frequently, e) Very frequently.

Section B includes seven questions intended to collect demographic details about the respondents. The demographic details cover name, age, gender, educa- 
tional qualification, occupation, income and period of membership.

\subsection{Data Collection}

For descriptive part of the study survey was conducted among six retailers (three retail companies) which include Levi's, Basics Life store's at Gulbarga and Peter England store's at Gulbarga, Bidar, Raichur and Bellary northern cities of Karnataka region. The only retailers which were running loyalty/reward program more than five years were selected since they are well versed in running reward program. A total of 540 samples were collected using self-administered survey method in eight month duration. This was sufficient period to collect data. Sincere efforts were made to get the list of members of loyalty programs of various identified retailers. But in order to maintain business confidentiality, the retailers were averse to provide the list. Hence, in absence of the sample frame Non probability method of sampling i.e. purposive sampling was used. Purposive sampling is a non-probability sampling technique and it occurs when "elements selected for the sample are chosen by the judgment of the researcher. Researchers often believe that they can obtain a representative sample by using a sound judgment, which will result in saving time and money" [34].

"Five subjects for one variable" was used for deciding the total number of subjects for the sample of the exploratory factor analysis according to [35]. Since there are 48 variables identified for this study, the ideal sample size should be $240\left(48^{\star} 5\right)$. The present sample is 540 , which exceeds this requirement. The member of a loyalty program is the sampling unit for this study. The member is one who has registered for retailer's loyalty program and renewing membership as per rules of the store. And only those members who have completed a year's membership were selected as these members have understood the operation and benefits of loyalty program. Total population size considering all the members of selected retailers was found to be 15,200 . Samples from each retailer were drawn proportionately as the size of the population was known.

Questionnaire was administered on all week days to ensure the heterogeneity of samples. Initially store managers had suggested to collect data from respondents after purchase process is over to avoid inconvenience to members. So, only those members who are willing to fill the questionnaire were given the questionnaire to get the valid response. Before administering the questionnaire, each member was briefed about the variables and purpose of this study to avoid biasness. A total of 540 valid questionnaires were obtained out of 615 questionnaires administered to collect data.

Table 1 shows the sample distribution among retailers. Through descriptive statistics it was found that 43.5 percent of the members surveyed were having membership period of 3 - 4 years, 34.3 percent were of $1-2$ years and only 22.2 percent were having membership period more than 4 years. 4 it was found that 34.4 percent of the members were between the age group of $21-25$ years, 31.1 percent were having age in the range of $26-30,18.7$ percent were $31-35$, 
Table 1. Sample distribution among retailers.

\begin{tabular}{cccc}
\hline Retailer Description & Total Members & Sample distributed & Valid sample \\
\hline Peter England, Gulbarga & 5500 & 226 & 195 \\
Basics Life, Gulbarga & 1500 & 61 & 54 \\
Levi's Gulbarga & 500 & 21 & 18 \\
Peter England, Bidar & 2500 & 102 & 88 \\
Peter England, Raichur & 2000 & 79 & 71 \\
Peter England, Bellary & 3200 & 126 & 114 \\
Total & 15,200 & 615 & 540 \\
\hline
\end{tabular}

only 7.8 percent of members were between $15-20$ years and lastly, 8 percent were having age more than 35 . And also it was found that, 47.4 percent were graduates, followed by PG which is 24.4 percent, 22.4 percent were PUC or less and only 5.7 percent of members were having higher qualifications. If we take occupation wise classification of respondents, it was found that, businessmen consists of 37.2 percent, followed by salaried persons which is 35.9 percent, 23.3 per cent were students, 1.3 percent of members were self employed and others form 2.2 percent.

The factor analysis performed to reduce the information contained in a number of variables into a few set of factors with a minimum loss of information, because this research consists of large number of variables, some of which are correlated and need to be reduced to a manageable level [36]. The study used exploratory factor analysis to develop a theoretical factor structure for concepts i.e., store attributes and loyalty program.

Multiple extraction methods are available in SPSS to extract the factors. Principal component factor analysis method is the most commonly used extraction method in social science research. In principal component analysis, the total variance in the data is considered. It is recommended when the primary concern is to determine the minimum number of factors that will account for maximum variance in the data for use in multivariate analysis. The factors are called principal components [35]. This method is more appropriate when identifying new meaningful underlying factors from the set of variables. Considering the objectives of this research, it was found that, principal component analysis is the appropriate method to extract the factors.

Interpretation is decided by identifying the variables that have large loadings on the same factor. That factor can be interpreted in terms of the variables that load high on it. Furthermore, items were selected if their communalities were greater than 0.30 , the difference of cross loadings were greater than 0.30 , and factor loadings were greater than 0.40 [36] [37]. The factor analysis results into five factors i.e. Store environment, Merchandise, Interpersonal communication, preferential treatment and Post transaction service with 16 items. Similarly in case of perceived benefits of loyalty program four factors were extracted i.e. Economy, Convenience, Information and Recognition-social relationship with 
12 items.

\subsection{Data Analysis}

A moderator is a variable that specifies conditions under which a given predictor is related to an outcome. The moderator explains "when" a Dependent Variable and Independent Variable are related. Moderation implied an interaction effect, where introducing a moderating variable changes the direction or magnitude of the relationship between two variables. A moderation effect could be 1) Enhancing, where increasing the moderator would increase the effect of the predictor (IV) on the outcome (DV);2) Buffering, where increasing the moderator would decrease the effect of the predictor on the outcome; or 3) Antagonistic, where increasing the moderator would reverse the effect of the predictor on the outcome. Moderation Hierarchical multiple regression is used to assess the effects of a moderating variable. To test moderation, we will be particularly looking at the interaction effect between $\mathrm{X}$ and $\mathrm{M}$ and whether or not such an effect is significant in predicting Y. Figure 1 shows the schematic representation of moderation analysis.

In this study, $\mathrm{X}$ is store attributes, $\mathrm{Y}$ is customer loyalty and $\mathrm{M}$ is Perceived benefits of loyalty programs.

\section{Factor Analysis}

Kaiser-Meyer-Olkin (KMO) measure of sample adequacy statistic was used to check the sample appropriateness which indicates the proportion of variance in variables that might be caused by underlying factors. This index ranges from 0 to 1 , reaching 1 when each variable is perfectly predicted without error by the other variables. The KMO value must exceed 0.50 for both the overall fit and each individual variable. The KMO measure for this sample is 0.854 , which indicate that the sample is adequate to run factor analysis. Similarly, KMO was computed for variables related to loyalty program concept, and the KMO value for this data set is 0.823 .

The result of total variance and eigenvalues of five factors are shown in Table 2. The table presents the total variance explained by the factor analysis solution and gives an indication about the number of useful factors. The first column "Initial Eigen values" gives the values for all the possible factors in a decreasing order. The second column shows "Extracted Sums of Squared Loadings" gives information on factors with eigenvalues greater than 1 after factor extraction.

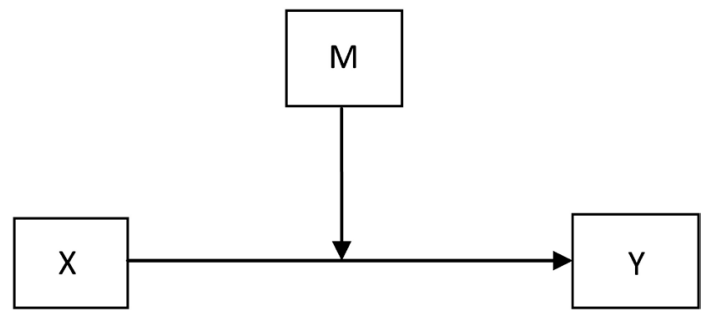

Figure 1. Moderation analysis. 
Table 2. Total variance explained (store attributes).

\begin{tabular}{|c|c|c|c|c|c|c|c|c|c|}
\hline \multirow{2}{*}{ Component - } & \multicolumn{3}{|c|}{ Initial Eigenvalues } & \multicolumn{3}{|c|}{ Extraction Sums of Squared Loadings } & \multicolumn{3}{|c|}{ Rotation Sums of Squared Loadings } \\
\hline & Total & $\%$ of Variance & Cumulative \% & Total & $\%$ of Variance & Cumulative \% & Total & $\%$ of Variance & Cumulative $\%$ \\
\hline 1 & 5.416 & 33.850 & 33.850 & 5.416 & 33.850 & 33.850 & 2.852 & 17.828 & 17.828 \\
\hline 2 & 1.855 & 11.595 & 45.445 & 1.855 & 11.595 & 45.445 & 2.666 & 16.660 & 34.488 \\
\hline 3 & 1.667 & 10.416 & 55.861 & 1.667 & 10.416 & 55.861 & 2.293 & 14.331 & 48.819 \\
\hline 4 & 1.527 & 9.542 & 65.403 & 1.527 & 9.542 & 65.403 & 2.246 & 14.039 & 62.858 \\
\hline 5 & 1.206 & 7.535 & 72.938 & 1.206 & 7.535 & 72.938 & 1.613 & 10.080 & 72.938 \\
\hline 6 & 0.536 & 3.349 & 76.287 & & & & & & \\
\hline 7 & 0.497 & 3.109 & 79.396 & & & & & & \\
\hline 8 & 0.481 & 3.006 & 82.402 & & & & & & \\
\hline 9 & 0.443 & 2.767 & 85.169 & & & & & & \\
\hline 10 & 0.401 & 2.507 & 87.676 & & & & & & \\
\hline 11 & 0.381 & 2.379 & 90.055 & & & & & & \\
\hline 12 & 0.363 & 2.269 & 92.324 & & & & & & \\
\hline 13 & 0.335 & 2.096 & 94.420 & & & & & & \\
\hline 14 & 0.329 & 2.055 & 96.475 & & & & & & \\
\hline 15 & 0.306 & 1.910 & 98.385 & & & & & & \\
\hline 16 & 0.258 & 1.615 & 100.000 & & & & & & \\
\hline
\end{tabular}

Extraction Method: Principal Component Analysis.

The "rotated sums of squared loadings" gives the information on the extracted factors after rotation. The value under the "cumulative \%" indicates that five extracted factors explain $72.93 \%$ of the variance.

Similarly Table 3 shows the total variance explained in case of perceived benefits of loyalty program which is $75.36 \%$. Three criteria were used to determine the factor structure: 1) Factor loadings more than 0.40 remained for further analysis, 2) items which cross load more than one factor were excluded, and 3) the difference between the cross loadings should be minimum 0.20 [35] [36].

A total of 16 items grouped under five factors of store attributes emerged from the factor analysis as shown in Table 4. And similarly 12 items were grouped under four factors of perceived benefits of loyalty program as shown in Table 5.

Interpreting the nature of variables and assigning meaning to the factors is an extremely important consideration in determining the number of factors to extract [37]. The five extracted factors are named based on the nature of variables, judgement by the academicians' and examination of the previous research studies. The five extracted factors of store attributes are: Store Environment, Interpersonal Communication, Merchandise, Preferential Treatment and Post Transaction Service. Similarly, the four extracted factors under loyalty program concept are: Recognition Social Relationship, Economy, Information and Convenience. 
Table 3. Total variance explained (loyalty program).

\begin{tabular}{|c|c|c|c|c|c|c|c|c|c|}
\hline \multirow{2}{*}{ Component } & \multicolumn{3}{|c|}{ Initial Eigen values } & \multicolumn{3}{|c|}{ Extraction Sums of Squared Loadings } & \multicolumn{3}{|c|}{ Rotation Sums of Squared Loadings } \\
\hline & Total & $\%$ of Variance & Cumulative \% & Total & $\%$ of Variance & Cumulative \% & Total & $\%$ of Variance & Cumulative \% \\
\hline 1 & 4.507 & 37.557 & 37.557 & 4.507 & 37.557 & 37.557 & 2.376 & 19.803 & 19.803 \\
\hline 2 & 1.891 & 15.757 & 53.314 & 1.891 & 15.757 & 53.314 & 2.319 & 19.323 & 39.126 \\
\hline 3 & 1.548 & 12.900 & 66.214 & 1.548 & 12.900 & 66.214 & 2.289 & 19.075 & 58.200 \\
\hline 4 & 1.098 & 9.153 & 75.367 & 1.098 & 9.153 & 75.367 & 2.060 & 17.166 & 75.367 \\
\hline 5 & 0.580 & 4.831 & 80.198 & & & & & & \\
\hline 6 & 0.419 & 3.494 & 83.691 & & & & & & \\
\hline 7 & 0.392 & 3.266 & 86.957 & & & & & & \\
\hline 8 & 0.373 & 3.105 & 90.062 & & & & & & \\
\hline 9 & 0.340 & 2.836 & 92.898 & & & & & & \\
\hline 10 & 0.336 & 2.803 & 95.701 & & & & & & \\
\hline 11 & 0.284 & 2.367 & 98.068 & & & & & & \\
\hline 12 & 0.232 & 1.932 & 100.000 & & & & & & \\
\hline
\end{tabular}

Extraction Method: Principal Component Analysis.

Table 4. Consolidated factor matrix (store attributes).

Variables

In general there was an attractive range of products

The quality of the products that I bought at this store met my expectations

I can find variety of products that satisfies my need

The price of the products sold by this store was acceptable

Signs and decoration in the store were pleasant and tasteful

The store spaces were visually appealing

It is spacious and easy to move about

The store was clean and fresh

The store has appropriate return policy and easy to return products

The store offered easy exchange services for products I purchased

The store's refund policy was appropriate

This store often holds personal conversation with me

This store takes the time to personally get to know me

This store often inquires about my personal welfare

This store takes utmost care for regular customers

This store makes greater efforts for regular customers than for non regular customers

$$
\begin{gathered}
\text { Eigen value } \\
\text { Variance\% } \\
\text { Cumulative\% } \\
\text { Cronbach's alpha }
\end{gathered}
$$

\begin{tabular}{|c|c|c|c|c|}
\hline SASE & SAME & SAIC & SAPT & SAPTS \\
\hline \multicolumn{5}{|l|}{0.856} \\
\hline \multicolumn{5}{|l|}{0.849} \\
\hline \multicolumn{5}{|l|}{0.782} \\
\hline \multicolumn{5}{|l|}{0.751} \\
\hline & 0.821 & & & \\
\hline & 0.773 & & & \\
\hline & 0.752 & & & \\
\hline & 0.743 & & & \\
\hline & & 0.863 & & \\
\hline & & 0.850 & & \\
\hline & & 0.821 & & \\
\hline & & & 0.842 & \\
\hline & & & 0.827 & \\
\hline & & & 0.798 & \\
\hline & & & & 0.872 \\
\hline & & & & 0.848 \\
\hline 5.41 & 1.85 & 1.66 & 1.52 & 1.20 \\
\hline 33.85 & 11.59 & 10.41 & 9.54 & 7.53 \\
\hline 17.82 & 34.48 & 48.81 & 62.85 & 72.93 \\
\hline 0.821 & 0.863 & 0.830 & 0.760 & 0.843 \\
\hline
\end{tabular}

\section{Components/Factors}

Extraction Method: Principal Component Analysis. Rotation Method: Varimax with Kaiser Normalization (Rotation Converged into 5 iterations). 
Table 5. Consolidated factor matrix (loyalty program).

\begin{tabular}{|c|c|c|c|c|}
\hline \multirow{2}{*}{ Description } & \multicolumn{4}{|c|}{ Components/ Factors } \\
\hline & LPEC & LPCON & LPINF & LPRSR \\
\hline Loyalty Program helps me to get financial benefit & 0.881 & & & \\
\hline Loyalty Program is the best means to reduce purchase amount & 0.848 & & & \\
\hline Loyalty Program allows me to make substantial economies & 0.821 & & & \\
\hline Being a member makes purchases easier & & 0.843 & & \\
\hline Loyalty Program allows me to find usual bought products & & 0.773 & & \\
\hline Loyalty Program grants additional services & & 0.729 & & \\
\hline Loyalty program allows me to discover good bargains & & & 0.859 & \\
\hline Being a member allows me to be well informed about general information & & & 0.844 & \\
\hline Loyalty program helps me to chose new products & & & 0.815 & \\
\hline Being a member makes me feel as if the store is paying more attention to me than others & & & & 0.883 \\
\hline Loyalty program makes me adhere to a group of privileged customer & & & & 0.856 \\
\hline Being a part of loyalty program makes the store treating me as a privileged customer & & & & 0.834 \\
\hline Eigen value & 4.50 & 1.89 & 1.54 & 1.09 \\
\hline Variance\% & 19.80 & 19.32 & 19.07 & 17.16 \\
\hline Cumulative\% & 19.80 & 39.12 & 58.20 & 75.36 \\
\hline Cronbach's alpha & 0.851 & 0.771 & 0.865 & 0.838 \\
\hline
\end{tabular}

\section{Moderation Analysis}

Model $=1$

$\mathrm{Y}=\mathrm{LOY}$

$\mathrm{X}=$ STATR

$\mathrm{M}=\mathrm{LPROG}$

Sample size: 540

Outcome: LOY

Table 6. Model summary.

\begin{tabular}{ccccccc}
\hline $\mathrm{P}$ & $\mathrm{R}$ & $\mathrm{R}^{2}$ & $\mathrm{MSE}$ & $\mathrm{F}$ & $\mathrm{df1}$ & $\mathrm{df2}$ \\
\hline 0.000 & 0.6049 & 0.3659 & 15.2186 & 118.91 & 3.0000 & 536.0000 \\
\hline
\end{tabular}

Table 7. Model.

\begin{tabular}{ccccccc}
\hline & Coeff & se & $\mathrm{t}$ & $\mathrm{P}$ & $\mathrm{LLC1}$ & $\mathrm{ULC1}$ \\
\hline Constant & 17.7299 & 0.1998 & 88.7192 & 0.0000 & 17.3373 & 18.1224 \\
LPROG & 0.1461 & 0.0211 & 6.9097 & 0.0000 & 0.1046 & 0.1887 \\
STATR & 0.1333 & 0.0174 & 7.6713 & 0.0000 & 0.0992 & 0.1674 \\
Int_1 & -0.0059 & 0.0011 & -5.2232 & 0.0000 & -0.0081 & -0.0037 \\
\hline
\end{tabular}

Interactions: Int_1 STATR X LPROG. 
Table 8. Conditional effect of $\mathrm{X}$ on $\mathrm{Y}$ at values of the moderator(s).

\begin{tabular}{ccccccc}
\hline LPROG & Effect & se & $t$ & P & LLC1 & ULC1 \\
\hline-9.7568 & 0.1991 & 0.0208 & 9.1913 & 0.000 & 0.1502 & 0.2319 \\
0.0000 & 0.1333 & 0.0174 & 7.6713 & 0.000 & 0.0992 & 0.1674 \\
9.7568 & 0.0755 & 0.0204 & 3.7005 & 0.002 & 0.0354 & 0.1156 \\
\hline
\end{tabular}

Values for quantitative moderators are the mean and plus/minus one SD from mean. Values for dichotomous moderators are the two values of the moderator. Level of confidence for all confidence intervals in output: 95.00. NOTE: The following variables were mean cantered prior to analysis: STATR LPROG. NOTE: All standard errors for continuous outcome models are based on the HC3 estimator.

Table 9. ANOVA: moderation analysis.

\begin{tabular}{cccccc}
\hline Model & Sum of Squares & df & Mean Square & F & Sig. \\
\hline 1 Regression & 4384.402 & 2 & 2192.201 & & \\
Residual & 8479.841 & 537 & 15.791 & 138.825 & 0.000 \\
Total & 12864.243 & 539 & & & \\
& & & & & \\
2 Regression & 4707.081 & 3 & 1569.027 & & \\
Residual & 8157.161 & 536 & 15.219 & 103.099 & 0.000 \\
Total & 12864.243 & 539 & & &
\end{tabular}

a) Dependent variable: LOY; b) Predictors: (constant), LPROG, STATR; c) Predictors: (constant), LPROG, STATR, STATXLPRG.

Table 10. Model summary: moderation analysis.

\begin{tabular}{ccccccccccc}
\hline & & & & & \multicolumn{5}{c}{ Change Statistics } \\
\cline { 6 - 10 } Model & $\mathrm{R}$ & $\begin{array}{c}\mathrm{R} \\
\text { Square }\end{array}$ & $\begin{array}{c}\text { Adjusted } \\
\text { R square }\end{array}$ & $\begin{array}{c}\text { Std error } \\
\text { of estimate }\end{array}$ & $\begin{array}{c}\text { R square } \\
\text { change }\end{array}$ & $\begin{array}{c}\mathrm{F} \\
\text { change }\end{array}$ & $\mathrm{df1}$ & $\mathrm{df2}$ & $\begin{array}{c}\text { Sig. } \\
\text { F change }\end{array}$ \\
\hline 1 & & 0.584 & 0.341 & 0.338 & 3.9738 & 0.341 & 138.825 & 2 & 537 & 0.000 \\
2 & 0.605 & 0.366 & 0.362 & 3.9011 & 0.025 & 21.203 & 1 & 536 & 0.000 \\
\hline
\end{tabular}

a) Predictors: (constant), LPROG, STATR; b) Predictors: (constant), LPROG, STATR, STATXLPRG; c) Dependent variable: LOYALTY.

Above Tables 6-8 shows the SPSS output of moderation analysis. Further, to test whether store attributes positively influences customer loyalty and more specifically whether perceived benefits of loyalty program moderates the relationship between store attributes and customer loyalty intention, a hierarchial multiple regression was conducted. In the first step, two variables were included: store attributes and perceived benefits of loyalty program. These variables accounted for significant amount of variance in loyalty, $\mathrm{R}$ square $=0.338, \mathrm{~F}(2$, $537)=138.82(\mathrm{P}=0.000)$. Next, the interaction term between store attribute and perceived benefits of loyalty program was added to the regression model, which accounted for significant amount of variance in loyalty, $\Delta \mathrm{R}^{2}=0.025, \mathrm{~F}(1,536)=$ $21.20(\mathrm{P}=0.000)$.

From Table 9 it was evident that both the models 1 and 2 are significant. Model 2 shows the more variance (with interaction) than model 1 (without interaction). From Table 10 it was noticed that $\mathrm{R}^{2}$ change $=0.025, \mathrm{P}=0.000$, indicating that 
there is potentially significant moderation effect of perceived benefits of loyalty program on the link between store attributes and loyalty.

\section{Discussion of Research Findings}

Store attribute items reduced to the following factors:

Store Environment-This factor refers to spaciousness, cleanliness, visual aspect, signs \& decoration of the store.

Merchandise-The items that describe this factor are variety, quality, attractive ranges of products, and price of the products available with the retailer.

Interpersonal Communication-The factor consists of time spent by retailers in having personal conversation with the customer, personally knowing the customers and their personal welfare.

Preferential treatment-This factor includes taking utmost care for regular customers, and making greater effort for regular customers than non-regular customers.

Post Transaction Service-This explains the items like refund policy, return policy and easy exchange services provided by the retail store.

Marketing research has recommended that vital store attributes differ by retail business contexts (Bianchi and Mena, 2007; Morschett et al., 2005; Stoel et al., 2004; Shim and Eastlick, 1998; Thang and Tan, 2003) [38] [39] [40] [41] [42] and the findings of this study authenticate the same. It is clear that, three store attributes less common in earlier studies appear to reveal store attributes distinctive to organized apparel retailers: merchandise, post-transaction service, and store atmosphere [42].

Items pertaining to Loyalty program reduced to the following factors:

Economy-This factor consists of items related to financial benefit, substantial economies (by being part of loyalty program), and reduction in the purchase amount by being part of loyalty program.

Convenience-This factor consists of items such as allowing member to find usual bought products, making purchases easier and granting additional services.

Recognition and Social Relationship-It refers to items such as treating customer as a privileged customer, making customer feel as if the store is paying more attention than others and helping the customer to adhere to a group of privileged customer.

Information-The items that explain this factor refers to providing general information; helping the customers to choose new products and discover good bargains.

Moderation Analysis-The results of moderation analysis performed using SPSS indicate that, perceived benefits of loyalty programs significantly moderate the relationship between stores attributes and customer loyalty. Hence, retailers need to manage their membership/loyalty program meticulously along with store attributes to ensure better customer loyalty. 


\section{Conclusion}

This research has filled gaps in customer loyalty domain by identifying the important variables and factors measuring loyalty in the context of apparel retailers. This study covers wide variety of the variables and dimensions measuring loyalty. The research found that, perceived benefits of loyalty programs are significantly moderating the relationship between store attributes and customer loyalty. And hence, the store to stress more in capitalizing the returns from loyalty programs and emphasizing the important store attribute factors identified in this study, to get the desired results in the long run. The non-probability method of sampling i.e., purposive sampling method however, due to unwillingness of retailers to disclose the list of loyalty members is the reason which limits the generalization of the findings. In future, the study may be conducted by considering other type of retail stores. In this study, the customers who are having a membership period of at least a year are considered. In future, researchers can take-up a study considering the customers having longer period of membership, so that deeper understanding about customer loyalty is possible.

\section{Conflicts of Interest}

The authors declare no conflicts of interest regarding the publication of this paper.

\section{References}

[1] Clark, N., Peck, H., Payne, A. and Christopher, M. (1995) Relationship Marketing: towards a New Paradigm. In: Payne, A., Ed., Advances in Relationship Marketing, Kogan Page, London.

[2] Kim, T., Kim, W.G. and Kim, H.B. (2009) The Effects of Perceived Justice on Recovery Satisfaction, Trust, Word-of-Mouth, and Revisit Intention in Upscale Hotels. Tourism Management, 30, 51-62.

[3] Lindgreen, A., Palmer, R., Vanhamme, J. and Wouters, J. (2006) A Relationship-Management Assessment Tool: Questioning, Identifying, and Prioritizing Critical Aspects of Customer Relationships. Industrial Marketing Management, 35, 57-71.

[4] Sheth, J.N. and Parvatiyar, A. (1992) Towards a Theory of Business Alliance Formation. Scandinavian International Business Review, 1, 71-87. https://doi.org/10.1016/0962-9262(92)90012-U

[5] Sheth, J.N. and Parvatiyar, A. (1995) The Evolution of Relationship Marketing. International Business Review, 4, 397-418. https://doi.org/10.1016/0969-5931(95)00018-6

[6] Odekerken-Schroder, G., De Wulf, K. and Schumacher, P. (2003) Strengthening Outcomes of Retailer-Consumer Relationships: The Dual Impact of Relationship Marketing Tactics and Consumer Personality. Journal of Business Research, 56, 177-190. https://doi.org/10.1016/S0148-2963(01)00219-3

[7] DeWulf, K., Odekerken-Schroder, G. and Iacobucci, D. (2001) Investments in Consumer Relationships: A Cross-Country and Cross-Industry Exploration. Journal of Marketing, 65, 33-50. https://doi.org/10.1509/jmkg.65.4.33.18386 
[8] De Wulf, K. and Odekerken-Schroder, G. (2003) Assessing the Impact of a Retailer's Relationship Efforts on Consumers' Attitudes and Behavior. Journal of Retailing and Consumer Services, 10, 95-108. https://doi.org/10.1016/S0969-6989(02)00013-9

[9] Roberts, K., Varki, S. and Brodie, R. (2003) Measuring the Quality of Relationships in Consumer Services: An Empirical Study. European Journal of Marketing, 37, 169-196. https://doi.org/10.1108/03090560310454037

[10] Wong, Y.H., Hung, H. and Chow, W.-K. (2007) Mediating Effects of Relationship Quality on Customer Relationships: An Empirical Study in Hong Kong. Marketing Intelligence \& Planning, 25, 581-596. https://doi.org/10.1108/02634500710819950

[11] Colgate, M.R. and Danaher, P.J. (2000) Implementing a Customer Relationship Strategy: The Asymmetric Impact of Poor versus Excellent Execution. Journal of the Academy of Marketing Science, 28, 375-387. https://doi.org/10.1177/0092070300283006

[12] Barnes, J.G. (1997) Closeness, Strength, and Satisfaction: Examining the Nature of Relationships between Providers of Financial Services and Their Retail Customers. Psychology \& Marketing, 14, 765-790. https://doi.org/10.1002/(SICI)1520-6793(199712)14:8<765::AID-MAR3>3.0.CO;2-C

[13] Kotler, P. (1973/1974) Atmospherics as a Marketing Tool. Journal of Retailing, 49, 48-64.

[14] Darden, W.R., Erdem, O. and Darden, D.K. (1983) A Comparison and Test of Three Causal Models of Patronage Intentions. In: Darden, W.R. and Lusc, R.F., Eds., Patronage Behavior and Retail Management, North-Holland, New York, 29-43.

[15] Odin, Y., Odin, N. and Valette-Florence, P. (2001) Conceptual and Operational Aspects of Brand Loyalty: An Empirical Investigation. Journal of Business Research, 53, 75-84. https://doi.org/10.1016/S0148-2963(99)00076-4

[16] Cunningham, R.M. (1956) Brand loyalty-What, Where, How Much. Harvard Business Review, 34, 116-128.

[17] Farley, J.U. (1964) "Brand Loyalty" and the Economics of Information. Journal of Business, 37, 370-381. https://doi.org/10.1086/294719

[18] DuWors Jr., R.E. and Haines Jr., G.H. (1990) Event History Analysis Measures of Brand Loyalty. Journal of Marketing Research, 27, 485-493. https://doi.org/10.1177/002224379002700410

[19] Shoemaker, S. and Lewis, R.C. (1999) Customer Loyalty: The Future of Hospitality Marketing. International Journal of Hospitality Management, 18, 345-370. https://doi.org/10.1016/S0278-4319(99)00042-0

[20] Kumar, V. and Shah, D. (2004) Building and Sustaining Profitable Customer Loyalty for 21st Century. Journal of Retailing, 80, 317-330. https://doi.org/10.1016/j.jretai.2004.10.007

[21] Pritchard, M.P., Howard, D.R. and Havitz, M.E. (1992) Loyalty Measurement: A Critical Examination and Theoretical Extension. Leisure Sciences, 14, 155-164. https://doi.org/10.1080/01490409209513164

[22] Mimouni-Chaabane, A. and Volle, P. (2010) Perceived Benefits of Loyalty Programs: Scale Development and Implications for Relational Strategies. Journal of Business Research, 63, 32-37. https://doi.org/10.1016/j.jbusres.2009.01.008

[23] Demoulin, N.T. and Zidda, P. (2008) On the Impact of Loyalty Cards on Store 
Loyalty: Does the Customers' Satisfaction with the Reward Scheme Matter? Journal of Retailing and Consumer Services, 15, 386-398. https://doi.org/10.1016/j.jretconser.2007.10.001

[24] Zeithaml, V.A. (1988) Consumer Perceptions of Price, Quality, and Value: A Means-End Model and Synthesis of Evidence. The Journal of Marketing, 52, 2-22. https://doi.org/10.1177/002224298805200302

[25] Holbrook, M.B. (1996) Special Session Summary. Customer Value-A Framework for Analysis and Research. Advances in Consumer Research, 23, 138-142.

[26] Bagchi, R. and Li, X. (2011) Illusionary Progress in Loyalty Programs: Magnitudes, Reward Distances, and Step-Size Ambiguity. Journal of Consumer Research, 37, 888-901. https://doi.org/10.1086/656392

[27] Frisou, J. and Yildiz, H. (2011) Consumer Learning as a Determinant of a Multi-Partner Loyalty Programs' Effectiveness: A Behaviorist and Long-Term Perspective. Journal of Retailing and Consumer Services, 18, 81-91. https://doi.org/10.1016/j.jretconser.2010.10.002

[28] Gable, M., Fiorito, S. and Topol, M. (2008) An Empirical Analysis of the Components of Retailer Customer Loyalty Programs. International Journal of Retail \& Distribution Management, 36, 32-49. https://doi.org/10.1108/09590550810846983

[29] Kwong, J.Y., Soman, D. and Ho, C.Y. (2011) The Role of Computational Ease on the Decision to Spend Loyalty Program Points. Journal of Consumer Psychology, 21, 146-156. https://doi.org/10.1016/j.jcps.2010.08.005

[30] Babin, B.J., Darden, W. and Griffin, M. (1994) Work and/or Fun: Measuring Hedonic and Utilitarian Shopping Value. Journal of Consumer Research, 20, 644-656. https://doi.org/10.1086/209376

[31] Chitturi, R., Raghunathan, R. and Mahajan, V. (2008) Delight by Design: The Role of Hedonic versus Utilitarian Benefits. Journal of Marketing, 72, 48-63.

[32] Drèze, X. and Nunes, J.C. (2011) Recurring Goals and Learning: The Impact of Successful Reward Attainment on Purchase Behavior. Journal of Marketing Research, 48, 268-281. https://doi.org/10.1509/jmkr.48.2.268

[33] Morais, D.B., Dorsch, M.J. and Backman, S.J. (2004) Can Tourism Providers Buy Their Customers' Loyalty? Examining the Influence of Customer-Provider Investments on Loyalty. Journal of Travel Research, 42, 235-243. https://doi.org/10.1177/0047287503258832

[34] Black, K. (2010) Business Statistics: Contemporary Decision Making. 6th Edition, John Wiley \& Sons, New York.

[35] Hair, J.F., Wolfinbarger, M.F., Ortinau, D.J. and Bush, R.P. (2008) Essentials of Marketing Research. McGraw-Hill/Higher Education, New York.

[36] Churchill Jr., G.A. (1979) A Paradigm for Developing Better Measures of Marketing Constructs. Journal of Marketing Research, 16, 64-73. https://doi.org/10.1177/002224377901600110

[37] Hair, J.F. (2006) Multivariate Data Analysis. Pearson Prentice, Hall Upper Saddle River, NJ.

[38] Bianchi, C. and Mena, J. (2007) Format Blurring and Attribute Saliency: Evidence in Chile. Revista Latinoamericana de Administracion, 40, 1-20.

[39] Morschett, D., Swoboda, B. and Foscht, T. (2005) Perception of Store Attributes and Overall Attitude towards Grocery Retailing: The Role of Shopping Motives. The International Review of Retail, Distribution and Consumer Research, 15, 423-447. https://doi.org/10.1080/09593960500197552 
[40] Stoel, L., Wickliffe, V. and Lee, K.H. (2004) Attribute Beliefs and Spending as Antecedents to Shopping Value. Journal of Business Research, 57, 1067-1073. https://doi.org/10.1016/S0148-2963(03)00016-X

[41] Shim, S. and Eastlick, M.A. (1998) The Hierarchical Influence of Personal Values on Mall Shopping Attitude and Behaviour. Journal of Retailing, 74, 139-160. https://doi.org/10.1016/S0022-4359(99)80091-8

[42] Thang, D. and Tan, B. (2003) Linking Consumer Perception to Preference of Retail Stores: An Empirical Assessment of the Multi-Attributes of Store Image. Journal of Retailing and Consumer Services, 10, 193-200.

https://doi.org/10.1016/S0969-6989(02)00006-1 